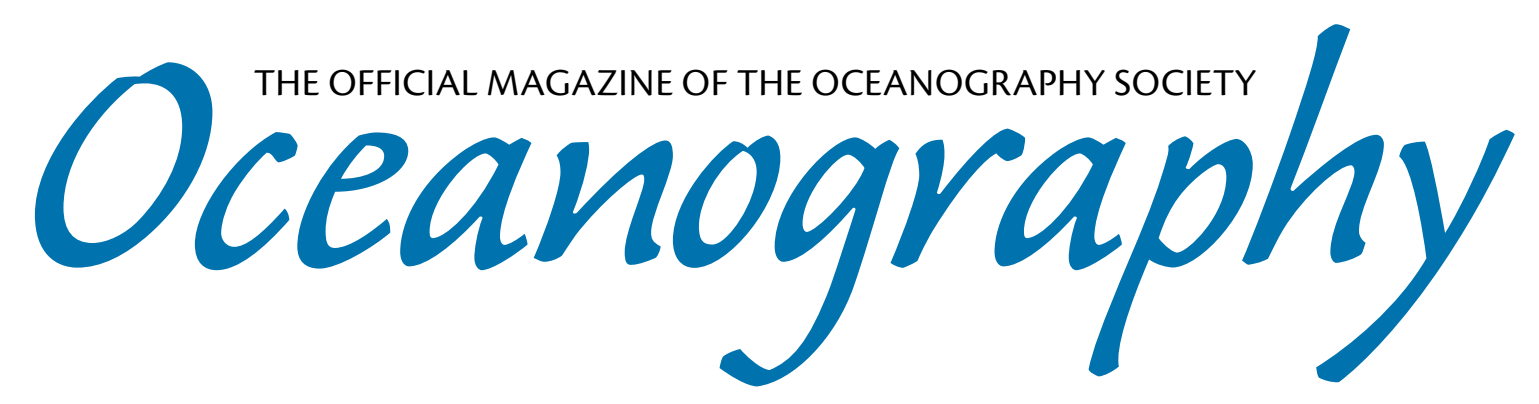

CITATION

Froelich, F. 2014. In praise of marine chemists. Oceanography 27(1):88-91,

http://dx.doi.org/10.5670/oceanog.2014.12.

DOI

http://dx.doi.org/10.5670/oceanog.2014.12

COPYRIGHT

This article has been published in Oceanography, Volume 27, Number 1, a quarterly journal of The Oceanography Society. Copyright 2014 by The Oceanography Society. All rights reserved.

USAGE

Permission is granted to copy this article for use in teaching and research. Republication, systematic reproduction, or collective redistribution of any portion of this article by photocopy machine, reposting, or other means is permitted only with the approval of The Oceanography Society. Send all correspondence to: info@tos.org or The Oceanography Society, PO Box 1931, Rockville, MD 20849-1931, USA. 
SPECIAL ISSUE ON CHANGING OCEAN CHEMISTRY»

ANTHROPOCENE: THE FUTURE...SO FAR

\section{In Praise of \\ Marine Chemists}

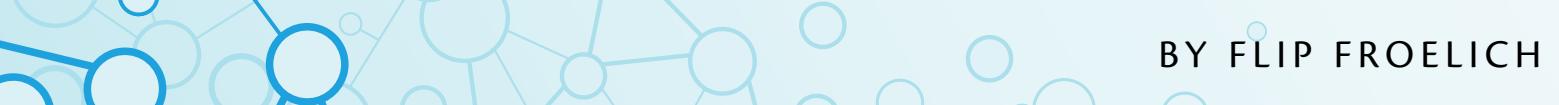

9

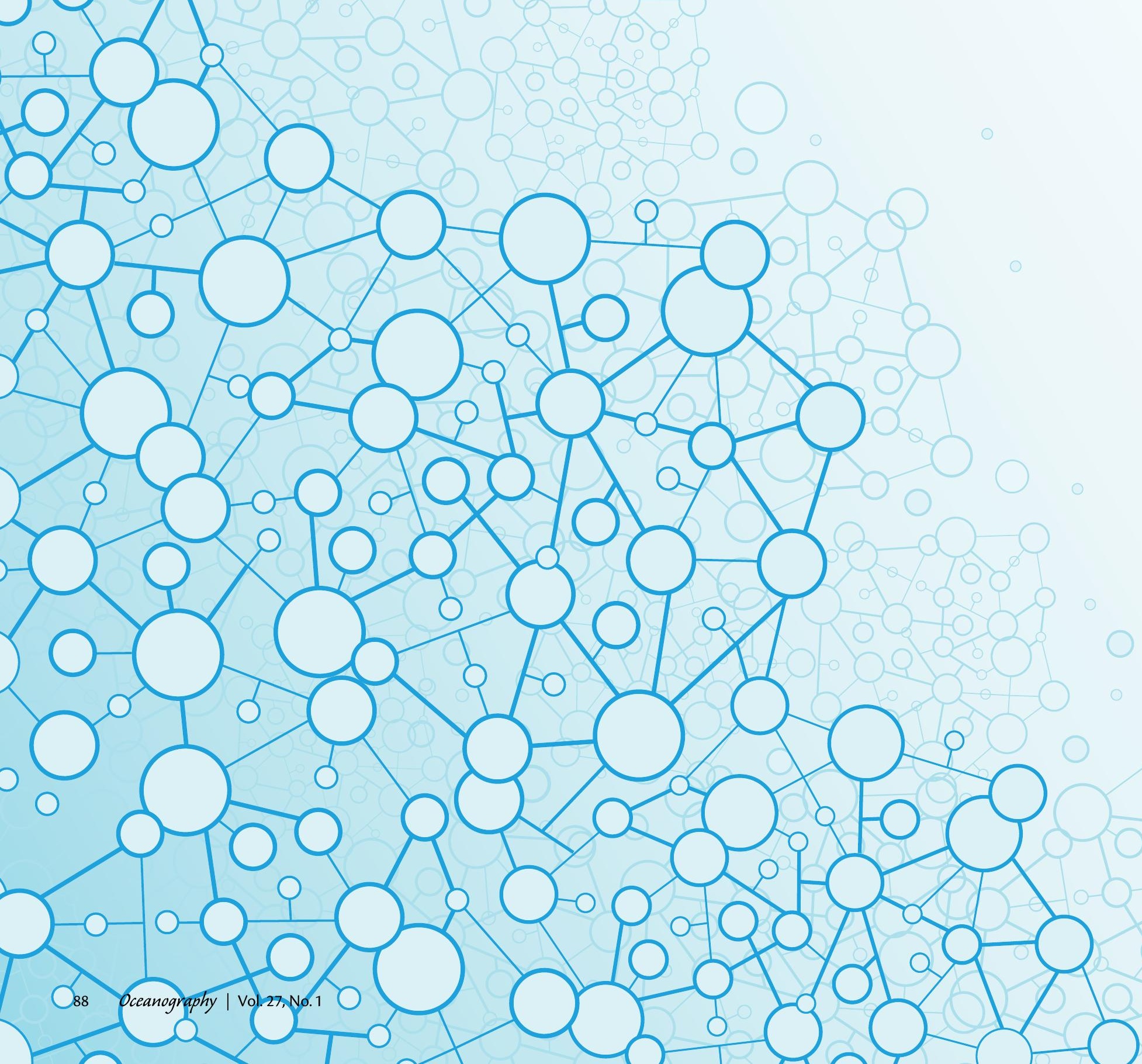


Shortly after the birth of the science of analytical chemistry, over 100 years ago, the art of measuring the chemicals in the sea began with the arduous task of analyzing the six major salts in seawater-sodium, magnesium, potassium, calcium, sulfate, and chloride. It soon became apparent that these four cations and two anions make up the bulk of sea salt, and a few more, like boron, strontium, fluorine, and bromine, were all "conservative." In other words, the salt composition of seawater was quite boring - the salts in seawater from anywhere in the world ocean contain almost exactly the same proportional composition as seawater from anywhere else-and in direct relationship to its "salinity" - a concept that originated with ocean chemists but was forfeited to ocean physicists when the chemical definition of salinity as a measure of salt mass content got corrupted and was no longer useful to calculate in situ seawater density.

In Nozaki's 2001 compilation of the vertical profiles of the elements and gases in the periodic chart (Figure 1), it is clear that only a small handful of the vertical profiles we have today are conservative. Most of the trace elements in the interior of the periodic chart-the first, second, and third row transition elements plus the lanthanides (rare earths) and actinides plus the metalloid elements out near the right-hand edge (Ge, As, Se, Sn, Sb, Te)-are not conservative but instead display distinct geochemical behaviors in their vertical profiles. These profile shapes helped to identify the likely vectors carrying each element into the deep sea (e.g., nutrient-like and thus bioactive, downward decreasing and thus scavenged, particulate reactive or surface ocean input, opal and carbonate vs. organic tissue) and hinted at the biochemistry involved (i.e., Ge substituting for $\mathrm{Si}$ in opal, $\mathrm{Zn}$ and Cd cofactors in carbonic anhydrase). These "smooth profiles" thus became criteria against which to judge the quality of later data sets.

The oldest citations in the Nozaki compilation date from about 1966 (though one from 1961 is the classic Noakes and Hood boron paper). Two 1966 papers (still cited today for the law of conservation) are Morris and Riley (on the bromide/chlorinity and sulfate/ chlorinity ratios) and Culkin and Cox (on sodium, potassium, magnesium, calcium, and strontium). A few rare gas papers also first appeared in 1964 and on lives of their own, lives often borrowed from the study of the geochemistry of Earth, the moon, and meteorites.

It was as if the ocean had just been discovered and a flotilla of chemists had been set loose to figure it out. The flotilla included Gerald Wasserburg, Harmon Craig, Karl Turekian, Ed Goldberg, Clair Patterson, John Edmond, John Martin, Ken Bruland, Ray Weiss, Ed Boyle-and the list goes on to include their students and grand-students. The major programs that made significant ocean biogeochemistry advances were GEOSECS (Geochemical Ocean Sections Study), VERTEX (Vertical Transport

\section{HE WHO DIES WITH THE MOST TOYS WINS.

1967: Mazor, Wasserburg, and Craig, and Craig, Weiss, and Clarke. Thus, I claim that the field of trace element and tracer marine chemistry essentially began after the mid-1960s and in earnest by the early 1970s. Before that, as Karl Turekian is reported to have stated (Danielsson, 1979): "Indeed, one has the feeling that the whole field of trace metal marine geochemistry would have been a completely dull one over the past [fifty] years if it weren't for analytical errors." And, he could have added, contamination artifacts. After that, analytical chemists camouflaged as seagoing oceanographers began to methodically pull apart the trace element and radioisotope systematics of the ocean's chemistry. Famous names and programs are splattered across these references, names that took and Exchange of Ocean Particulate Program), BATS (Bermuda-Atlantic Time-series Study), HOT (Hawaii Ocean Time-series), and many others. These programs also took on lives of their own. To quote Turekian again (Edmond, 1980): "GEOSECS is like the Yankees: Everyone hates it and it always wins." I always suspected Karl had come to the late realization that oceanographers are a collective lot-all for one and one for all. Just so long as the one gets the right answer and that the answer makes “oceanographic sense."

The success of the Nozaki compilation, and ocean tracer chemistry in general, derived from the paranoid realization in the 1970s and 1980s that marine chemists had to figure out how to collect pristine (uncompromised) samples from 


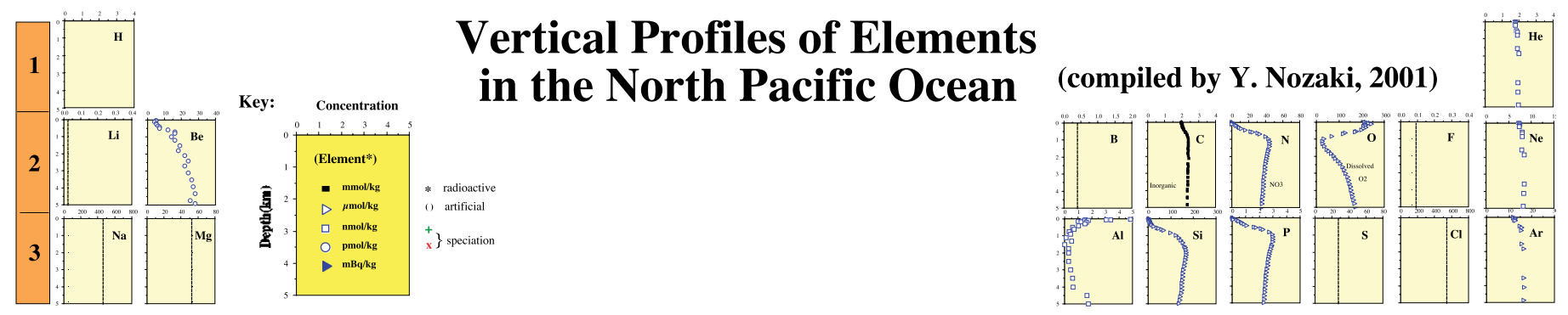

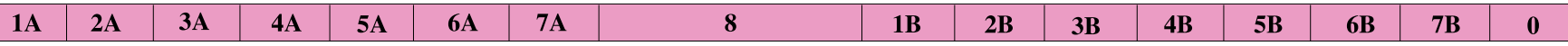

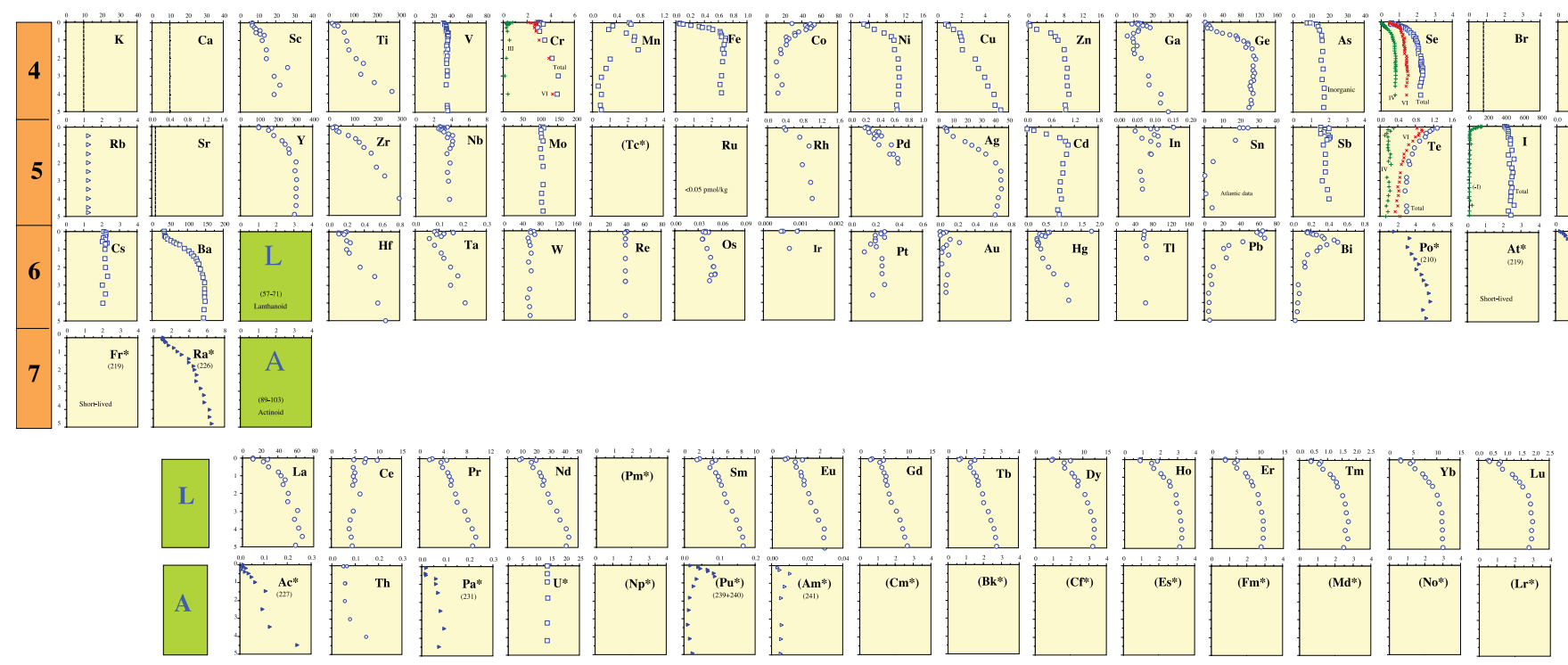

Figure 1. Vertical profiles of elements in the North Pacific Ocean. Reprinted from Nozaki (2001) with permission from Elsevier

an ocean that was unforgiving: they had to get them out of the ocean and out of the sampling device and delivered back home to the lab (that is, storing and transporting bottles) without transformation of the seawater contained inside (no sorption onto bottle walls, no biological activity, and no contamination from the accelerators and plasticizers in the bottles themselves), and then they had to do the lab work (column concentrations and separations of interfering components and the final analyses, the analytical chemistry part). Sampling gear had to be designed, fabricated, and

Flip Froelich (pfroelich@comcast.net) is Chief Scientist, Froelich Education Services, Tallahassee, FL, USA. tested to avoid trace metal contamination from rusting steel hydro cables, from painted steel boats (both the hulls, the houses, and the interior labs), or from the conductivity-temperaturedepth (CTD) rosette itself (Fe, Co, $\mathrm{Ni}$, $\mathrm{Cu}, \mathrm{V}, \mathrm{Cr}, \mathrm{Mn}, \mathrm{Zn}$....... Al, Ti) or in the background atmosphere (dust $\mathrm{Al}$ and $\mathrm{Fe}$, ship's stack exhaust, tailpipe fine phase $\mathrm{Pb})$. Chemists went to sea sheathed in plastic and bathed in acid. Boyle devised his "weather vane" water suckers that clamp onto the wire individually and sample water "upwind" of the hydro wire (see Boyle et al., 2014, in this issue). The $\mathrm{Al}$ and $\mathrm{Fe}$ groups devised their own metal-free rosette and its bottles, and hung them on their own one-of-a-kind 1,000 m Kevlar cable (see Grand et al.,
2014, in this issue). Things that go into the ocean often don't come back and are thus best interpreted as expendableas Bill Landing, Chris Measures, and scientific crew discovered when their Kevlar cable parted and their rosette ended up on the bottom in the Southern Ocean. The worst actor of the elemental lot-mercury-proved recalcitrant until recently because of its obtuse speciation (liquid, vapor, redox, and methylated) and tendency to stick to anything and everything (see Lamborg et al., 2014, in this issue). MeHg is second only to plutonium in its toxicity. Despite decades of work elucidating the Hg-biomethylation process by sulfate reducing bacteria in anaerobic sediments, the open ocean processes leading to biomethylation and 
bioaccumulation of this toxin at the top of the pelagic food chain remained enigmatic. Just last year, the first reliable isotopic values for $\mathrm{MeHg}$ in seawater were published (Blum et al., 2013).

Today, this practice of trace element paranoia is universally accepted. Modern lab instrumentation involves mass spectrometers (MC-ICP-MS) with hyphenated front-end chemistries (HG, GC, LC, HPLC, CE, ESI, MALDI-the list is almost endless) with incredible selectivity and sensitivity, enabling isotopic values for speciation arrays that are down in the picomolar $\left(10^{-12} \mathrm{M}\right)$ concentration range.

Who is going to update Nozaki's chart? The new challenges are to produce a three-dimensional version of the Nozaki chart that includes not only the redox behavior (although by 2001 many of the major redox elements had been sorted out) but also isotopic signatures by speciation for the "nontraditional stable isotopes" - those other than carbon, sulfur, hydrogen, nitrogen, and oxygen. Thus, the international GEOTRACES program is building on its predecessors, especially GEOSECS, to obtain time and space "TEI" maps-trace element and isotope profiles and sections (see Anderson et al., 2014, in this issue). This "TEI" mapping holds out the hope of unraveling the processes involved in elemental and compositional sources, sinks, transformation mechanisms, and transport, a sort of biogeochemical blood screen for the planet as reference for future ailments. These sorts of time and space snapshots will become more and more important as time goes by and the burgeoning human population living on the edges of the ocean has greater and greater impact on the seas. The game is afoot-the quarry is not only the inorganic ultra trace elements and their isotopes, but also the trace man-made synthetic organic compounds and particles that are showing up in the environment as harbingers of human domination of the planet (see Farrington et al., 2014, in this issue). The tool kit of the next generation of analytical marine chemists will need more and better toys to marry the organic and inorganic trace components and isotopes in the sea.

\section{REFERENCES}

Anderson, R.F., E. Mawji, G.A. Cutter, C.I. Measures, and C. Jeandel. 2014. GEOTRACES: Changing the way we explore ocean chemistry. Oceanography 27(1):50-61, http://dx.doi.org/10.5670/oceanog.2014.07.

Blum, J., B.N. Popp, J.C. Drazen, C.A. Choy, and M.W. Johnson. 2013. Methylmercury production below the mixed layer in the North Pacific Ocean. Nature Geoscience 6:879-884, http:// dx.doi.org/10.1038/ngeo1918.

Boyle, E.A., J.-M. Lee, Y. Echegoyen, A. Noble, S. Moos, G. Carrasco, N. Zhao, R. Kayser, J. Zhang, T. Gamo, H. Obata, and K. Norisuye. 2014. Anthropogenic lead emissions in the ocean: The evolving global experiment. Oceanography 27(1):69-75, http://dx.doi.org/ 10.5670/oceanog.2014.10.

Craig, H., R.F. Weiss, and W.B. Clarke. 1967. Dissolved gases in Equatorial and South Pacific Ocean. Journal of Geophysical Research 72:6,165-6,181, http://dx.doi.org/ 10.1029/JZ072i024p06165.

Culkin, F., and R.A. Cox. 1966. Sodium, potassium, magnesium, calcium and strontium in seawater. Deep Sea Research 13:789-804, http:// dx.doi.org/10.1016/0011-7471(76)90905-0.

Danielsson, L.-G. 1979. Trace metals in marine waters: Analytical investigations on cadmium, cobalt, copper, iron, lead, nickel and zinc. $\mathrm{PhD}$ Thesis, University of Gothenburg.

Edmond, J. 1980. GEOSECS is like the Yankees: everybody hates it and it always wins... K.K. Turekian (1978). Oceanus 23(1):33-39. Available online at: http://www.biodiversitylibrary.org/ia/ oceanusv2301wood\#page/37/mode/1up (accessed December 23, 2013).

Farrington, J.W., and H. Takada. 2014. Persistent organic pollutants (POPs), polycyclic aromatic hydrocarbons (PAHs), and plastics: Examples of the status, trend, and cycling of organic chemicals of environmental concern in the ocean. Oceanography 27(1):196-213, http://dx.doi.org/ 10.5670/oceanog.2014.23.

Grand, M.M., C.S. Buck, W.M. Landing, C.I. Measures, M. Hatta, W.T. Hiscock, M. Brown, and J.A. Resing. 2014. Quantifying the impact of atmospheric deposition on the biogeochemistry of $\mathrm{Fe}$ and $\mathrm{Al}$ in the upper ocean: A decade of collaboration with the US CLIVAR- $\mathrm{CO}_{2}$ Repeat Hydrography Program. Oceanography 27(1):62-65, http:// dx.doi.org/10.5670/oceanog.2014.08.

Lamborg, C., K. Bowman, C. Hammerschmidt, C. Gilmour, K. Munson, N. Selin, and C.-M. Tseng. 2014. Mercury in the Anthropocene ocean. Oceanography 27(1):76-87, http://dx.doi.org/ 10.5670/oceanog.2014.11.

Mazor, E., G.J. Wasserburg, and H. Craig. 1964. Rare gases in Pacific Ocean water. Deep Sea Research 11:929-932, http://dx.doi.org/ 10.1016/0011-7471(64)90343-2.

Morris, A.W., and J.P. Riley. 1966. The bromide/ chlorinity and sulphate/chlorinity ratio in seawater. Deep Sea Research 13:669-705, http:// dx.doi.org/10.1016/0011-7471(66)90601-2.

Noakes, J.E., and D.W. Hood. 1961. Boronboric acid complexes in sea water. Deep Sea Research 8:121-129, http://dx.doi.org/ 10.1016/0146-6313(61)90004-1.

Nozaki, Y. 2001. Elemental distribution: Overview. Pp. 840-845 in Encyclopedia of Ocean Sciences, vol. 2. J.H. Steele, S.A. Thorpe, and K.K. Turekian, eds, Academic Press, London, http://dx.doi.org/10.1006/rwos.2001.0402. 